Journal of Animal and Veterinary Advances 11 (17): 3202-3205, 2012

ISSN: $1680-5593$

(C) Medwell Journals, 2012

\title{
Effects of Methanol Extract of Morus alba on Hematological Parameters and Liver Histology of African Catfish (Clarias gariepinus)
}

\author{
${ }^{1}$ A. Sheikhlar, ${ }^{1}$ A.R. Alimon, ${ }^{2}$ H.M. Daud and ${ }^{3}$ C.R. Saad \\ ${ }^{1}$ Department of Animal Science, Faculty of Agriculture, \\ ${ }^{2}$ Aquatic Animal Health Unit, Department of Veterinary Clinical Studies, \\ Faculty of Veterinary Medicine, \\ ${ }^{3}$ Department of Aquaculture, Faculty of Agriculture, Universiti Putra Malaysia, \\ 43400 UPM Serdang, Selangor, Malaysia
}

\begin{abstract}
Methanol extract of Morus alba Foliage (MFE) was studied to evaluate its effect on hematological parameters and liver histology of African catfish (Clarias gariepinus). The trial consisted of five diets preparation, i.e., control diet (diet 1) and four tested diets supplemented, respectively with $2 \mathrm{~g} \mathrm{MFE} \mathrm{kg}^{-1}$ (MFE-2), $5 \mathrm{~g} \mathrm{MFE} \mathrm{kg}^{-1}$ (MFE -5), $7 \mathrm{~g} \mathrm{MFE} \mathrm{kg}^{-1}$ (MFE -7) and $9 \mathrm{~g} \mathrm{MFE} \mathrm{kg}^{-1}$ (MFE -9) of Dry Matter (DM) diet. Results showed fish fed with MFE-5 and MFE-7 diets had $(\mathrm{p}<0.05)$ the highest RBC counts, Hb content, albumin and total protein levels among other dietary groups while MFE-9 showed the poorest RBC, albumin and total protein. Histological study indicated that fish received MFE-9 diet showed minor degenerative changes in the liver. In conclusion, methanol extract of Morus alba at $7 \mathrm{~g} \mathrm{~kg}^{-1}$ of diet has no adverse impact on hematology and liver's histology in African catfish.
\end{abstract}

Key words: Clarias gariepinus, Morus alba extract, hematological parameters, liver histology, MFE-9, Malaysia

\section{INTRODUCTION}

The epidemic diseases are the limiting factors in aquaculture industry. Most of aquatic farms and hatcheries have been utilizing various types of antibiotics, vaccines and chemotherapeutic medicines to prevent the microbial diseases for many years. However, some of these drugs, antibiotics in particular were recently banned due to numerous disadvantages including high costs, limited efficacies, developing resistant strains and public health concern. On the other hand, medicinal plants and their bio-active ingredients are becoming attractive alternative. There are increasing numbers of new herbal medicines and by-products which are being isolated and identified. They have enormous therapeutic capacities and are effective in the cure of various diseases. However, they might simultaneously have some side effects and toxicities. Even though the common belief says that herbal medicines and their phyto-compounds are safe, they all have potential risks similar to synthetic drugs.

Histopathological and hematological assessments are important ways for the diagnosis of the main cause of any disorder. Furthermore, the liver function test is of considerable importance to monitor the adverse effects of inclusion of any additive because if a new product is ingested and the body is not able to convert its foreign ingredients into cellular components and excreted, it would be manifested by changes in liver's enzyme concentrations and the hepatocytes cellular components. The enzymes which mainly involves are: Aspartate amino Transferase (AST), Alanine Aminotransferase (ALT) and Alkaline Phosphatase (ALP). In addition, the toxicity could cause tissue or organ damage and the target organs which are mostly affected are liver, kidney and heart. Therefore, histological assessment of the vulnerable organs will also assist to detect the possible cytotoxicity. Morus alba (white mulberry) is a hedge plant which grows quickly. Its height reaches up to $35 \mathrm{~m}$ high and the diameter is around $1.8 \mathrm{~m}$ (Orwa et al., 2009). Its leaf has a considerable quantity of protein, carbohydrate, fat, fiber, minerals and some vitamins or their precursors. Analyzing Morus alba's phyto-compounds showed that the constituents were tannins, flavonoids, alkaloids, saponins, volatile oils, phenolics and terpenoids (Kusano et al., 2002; Enkhmaa et al., 2005; Kang et al., 2006). Morus alba has been known for its therapeutic potential as well. According to Ahmad and Beg (2001) Morus alba leaves alcohol extract revealed strong antimicrobial activity against Staphylococcus aureus, Salmonella paratyphi and Shigella dysenteriae (in vitro)

Corresponding Author: Hassan Mohd. Daud, Aquatic Animal Health Unit, Department of Veterinary Clinical Studies, Faculty of Veterinary Medicine, Universiti Putra Malaysia, 43400 UPM Serdang, Selangor, Malaysia 
Morus alba leaves is known as antihyperglycemic nutraceutical for patients with diabetes mellitus (Kim et al., 2003; Miyahara et al., 2004; Oku et al., 1982). Root bark of mulberry holds several constituents with antiviral potential as demonstrated by Du et al. (2003) who pointed out antiviral potential for leachianone $G$, an ingredient derived from root bark, against Herpes Simplex type 1 Virus (HSV-1). Morus alba leaf extract was also shown as a non-toxic natural therapeutic agent in rats (Abdulla et al., 2009). There is however, no information on the effect of dietary inclusion of Morus alba Foliage Methanol Extract (MFE) in fish. Therefore, the objective of the present study was to investigate the effect of the crude methanol extract of Morus alba on the hematological and biochemical parameters and histology of liver and kidney in African catfish (Clarias gariepinus).

\section{MATERIALS AND METHODS}

Herbal collection and methanol extract preparation: The fresh Morus alba foliage were washed in sterile distilled water for several times. They were then air dried for 10 days until constant weight was achieved. The herb was finely chopped using electric blender. To prepare methanol extracts, $100 \mathrm{~g}$ sample of the finely chopped plant was added into the conical flask containing $1 \mathrm{~L}$ of $95 \%$ methanol. The flask was tightly covered and left for 7 days at room temperature with daily agitation. The supernatant was then removed and the methanol was evaporated using a rotary evaporator. The extract was freeze-dried and stored in a sterile bottle at $-20^{\circ} \mathrm{C}$ until used (Harikrishnan et al., 2009).

Fish and rearing system: African catfish (Clarias gariepinus) were purchased from a local farm and fed with commercial diet for 2 weeks to acclimatize. Thereafter, the fish were weighed and kept in $100 \mathrm{~L}$ aquaria with 30 fish per aquarium. The initial body weight per fish was $9.5 \pm 0.4 \mathrm{~g}$. In the experiment, a basal diet was formulated based on the NRC (1993) recommendation. This diet was considered as control diet (diet 1) and additional four diets were the control diet supplemented with $2 \mathrm{~g} \mathrm{MFE} \mathrm{kg}^{-1}$ (MFE-2), $5 \mathrm{~g} \mathrm{MFE} \mathrm{kg}^{-1}$ (MFE-5), $7 \mathrm{~g} \mathrm{MFE} \mathrm{kg}^{-1}$ (MFE-7) and $9 \mathrm{~g} \mathrm{MFE} \mathrm{kg}^{-1}$ (MFE-9) g MFE $\mathrm{kg}^{-1}$ of Dry Matter (DM) diet. Each experimental diet was fed to three replicates of fish groups over a period of 60 days. All fish were hand-fed two times daily at $4 \%$ of body weight. All aquaria were cleaned weekly and the water quality parameters were checked daily.

Blood sampling: At the end of the study, blood samples were taken $24 \mathrm{~h}$ after the last feeding. First, fish were first anesthetized using $50 \mathrm{mg} \mathrm{L}^{-1}$ tricaine Methanesulfonate (MS-222). The blood samples were collected from the caudal vein of fish randomly selected from each replicate for determination of blood parameters including Red Blood Cells (RBC), White Blood Cells (WBC), Hematocrit $(\mathrm{Ht})$ and Hemoglobin $(\mathrm{Hb})$ (Hesser, 1960; Larsen and Snieszko, 1961; Larsen, 1964; Houston, 1990; Van Kampen and Zijlstra (1961).

The serum was considered for determination of t-albumin, globulin and activities of Alanine amino Transferase (ALT), Aspartate amino Transferase (AST) and Alkaline Phosphatase (ALP) using commercial kits and an auto-analyzer (Technicon RA-1000). The fish were euthanized in a solution of $200 \mathrm{mg} \mathrm{L}^{-1} \mathrm{MS}-222$ and livers were removed for histological examination. The liver tissues were fixed in $10 \%$ buffered formalin for at least $72 \mathrm{~h}$. The fixed tissue was then processed using automatic tissue processing by dehydration, clearing and paraffin wax infiltration for $24 \mathrm{~h}$. The paraffin embedded tissues were cut at $5 \mu \mathrm{m}$ with a microtome (JB, 2035; Leica). Triplicate sections of each block were prepared. The slides were then stained with routine hematoxylin and eosin before being examined using the light microscope.

Statistical analysis: The data analyzed by the GLM procedure of SAS Institute (1990). The differences between means were analyzed at the $5 \%$ probability level using Duncan's new multiple range test. Each aquarium was considered as an experimental unit.

\section{RESULTS}

Hematological parameters: The results of hematological values are shown in Table 1. It could be seen that the fish fed with MFE-7 diet had the highest RBC cell numbers, $\mathrm{Hb}$ content, albumin and total protein levels among other dietary groups $(\mathrm{p}<0.05)$ and MFE-9 showed the poorest $\mathrm{RBC}$, albumin and total protein responses. White blood cells, hematocrit and globulin values did not differ between the MFE supplemented diets and control. Biochemical parameters included ALT and ALP of the fish fed with different dietary groups showed no differences ( $>0.05$ ) however, they had the highest values for the MFE-9 diet. Fish received the MFE-9 diet had highest AST $(\mathrm{p}<0.05)($ Table 2$)$.

Histological assessment: Histological examination indicated some changes in the liver of fish fed diets supplemented with MFE-9 (Fig. 1). Livers of fish fed the control, MFE-2, MFE-5 and MFE-7 diets were normal and exhibited regular-shaped and uniform hepatocytes with centrally placed nuclei and some lipidic vacuoles in the 
Table 1: Changes in RBCs, WBCs, $\mathrm{Hb}$ content, hematocrit albumin and globulin of African catfish fed with different amounts $\left(2,5,7\right.$ and $9 \mathrm{~g} \mathrm{~kg}^{-1} \mathrm{dry} \mathrm{diet)}$ of Morus alba Foliage Extract (MFE) at the end of a 60 days experimental period

\begin{tabular}{|c|c|c|c|c|c|c|}
\hline Treatments & $\operatorname{RBCs}\left(10^{6} \mu \mathrm{L}^{-1}\right)$ & WBCs $\left(10^{5} \mu \mathrm{L}^{-1}\right)$ & Hemoglobin $\left(\mathrm{g} \mathrm{dL}^{-1}\right)$ & Hematocrit (\%) & 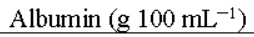 & Globulin $\left(\mathrm{g} 100 \mathrm{~mL}^{-1}\right)$ \\
\hline Control & $2.43 \pm 0.07^{b}$ & $3.70 \pm 0.14$ & $8.98 \pm 0.25^{b}$ & $34.5 \pm 3.6$ & $22.9 \pm 2.0^{b}$ & $17.2 \pm 1.9$ \\
\hline MFE-2 & $2.47 \pm 0.04^{\mathrm{ab}}$ & $3.78 \pm 0.06$ & $9.27 \pm 0.31^{b}$ & $35.8 \pm 2.5$ & $24.5 \pm 2.7^{b}$ & $15.1 \pm 1.3$ \\
\hline MFE-5 & $2.50 \pm 0.05^{\mathrm{ab}}$ & $3.73 \pm 0.11$ & $9.32 \pm 0.26^{b}$ & $37.1 \pm 3.2$ & $26.5 \pm 1.3^{b}$ & $16.1 \pm 1.7$ \\
\hline MFE-7 & $2.54 \pm 0.03^{\mathrm{a}}$ & $3.86 \pm 0.09$ & $10.70 \pm 0.34^{\mathrm{a}}$ & $40.0 \pm 3.8$ & $31.5 \pm 1.7^{\mathrm{a}}$ & $17.9 \pm 1.2$ \\
\hline MFE-9 & $2.10 \pm 0.07^{\mathrm{c}}$ & $3.85 \pm 0.10$ & $8.86 \pm 0.42^{b}$ & $33.6 \pm 3.7$ & $14.8 \pm 2.5^{c}$ & $14.9 \pm 1.7$ \\
\hline
\end{tabular}

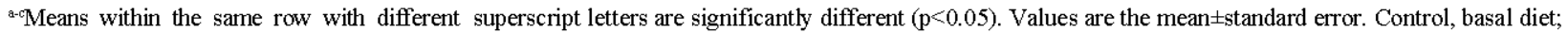
MFE-2, MFE-5, MFE-7 and MFE-9 were basal diet plus 2, 5, 7 and $9 \mathrm{~g} \mathrm{~kg}^{-1}$ of dry diet of Morus alba foliage extract, respectively

Table 2: Changes in total protein, Aspartate amninotransferase (AST), Alanine Aminotransferase (ALT) and Alkaline Phosphatase (ALP) $($ mean \pm SE) of African catfish fed different amounts $(2,5,7$ and $9 \mathrm{~g} \mathrm{~kg}^{-1}$ dry diet) of Morus alba Foliage Extract (MFE) at the end of a 60 days experimental period

\begin{tabular}{lcccc}
\hline Treatments & $\begin{array}{c}\text { Total protein } \\
\left(\mathrm{g} 100 \mathrm{~mL}^{-1}\right)\end{array}$ & $\begin{array}{c}\text { AST } \\
\left(\mathrm{IU} \mathrm{L}^{-1}\right)\end{array}$ & $\begin{array}{c}\text { ALT } \\
\left(\mathrm{IU} \mathrm{L}^{-1}\right)\end{array}$ & $\begin{array}{c}\text { ALP } \\
\left(\mathrm{IU} \mathrm{L}^{-1}\right)\end{array}$ \\
\hline Control & $40.1 \pm 1.9^{\mathrm{b}}$ & $23.4 \pm 2.8^{\mathrm{b}}$ & $28.5 \pm 4.6$ & $30.8 \pm 5.9$ \\
MFE-2 & $39.6 \pm 2.0^{b}$ & $24.2 \pm 3.9^{b}$ & $26.7 \pm 5.5$ & $32.2 \pm 4.5$ \\
MFE-5 & $42.6 \pm 1.5^{\mathrm{b}}$ & $29.6 \pm 4.6^{\mathrm{ab}}$ & $33.1 \pm 4.3$ & $29.4 \pm 5.3$ \\
MFE-7 & $49.4 \pm 1.4^{\mathrm{a}}$ & $30.7 \pm 3.4^{\mathrm{ab}}$ & $31.8 \pm 3.5$ & $34.3 \pm 5.1$ \\
MFE-9 & $29.7 \pm 2.1^{\mathrm{c}}$ & $33.4 \pm 2.2^{\mathrm{a}}$ & $34.2 \pm 5.0$ & $40.2 \pm 6.2$ \\
\hline
\end{tabular}

${ }^{\mathrm{a}-\mathrm{c}}$ Means within the same row with different superscript letters are significantly different $(\mathrm{p}<0.05)$. Values are the mean \pm standard error. Control, basal diet; MFE-2, MFE-5, MFE-7 and MFE-9 were basal diet plus 2, 5, 7 and $9 \mathrm{~g} \mathrm{~kg}^{-1}$ of dry diet of Morus alba foliage extract, respectively

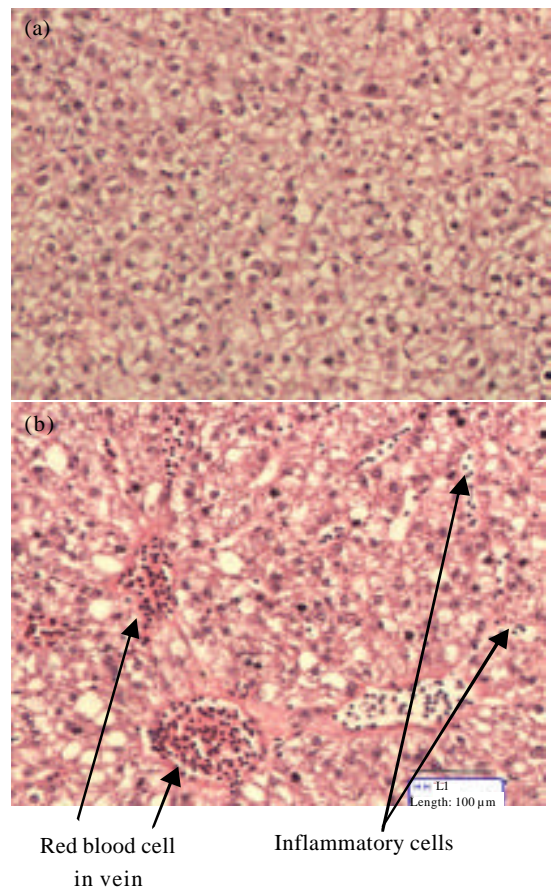

Fig. 1: Histological appearance of the liver tissue. a) fish fed control diet (without extract); b) fish fed $9 \mathrm{~g} \mathrm{~kg}^{-1}$ Morus alba foliage extract ( $\mathrm{H}$ and $\mathrm{E}$ stain magnification $200 \mathrm{x}$ ) at the end of 60 days feeding study

cytoplasm that did not disturb the hepatocytes size (Fig. 1). In contrast, the fish received MFE-9 diet showed some degenerated hepatocytes and also revealed numerous inflammatory cells in inter cellular spaces and in hepatic blood vessels.

\section{DISCUSSION}

Hematological indices have been shown to be precious tools in indicating the health status of the fish in response to the dietary changes (Congleton and Wagner, 2006; Mohammed and Sambo, 2008). In the study, hematological study revealed that $\mathrm{RBCs}$ and $\mathrm{Hb}$ levels were higher compared to control group when fish were fed diet supplemented with diets with MFE (at $7 \mathrm{~g} \mathrm{~kg}^{-1}$ of diet). Also, albumin and total protein levels in fish fed with MFE (at $7 \mathrm{~g} \mathrm{~kg}^{-1}$ of diet) supplemented diet increased pronouncedly in comparison to control group. These improvements may reflect the good nutrients balance and immunity enhancement in fish. While by increasing the levels of MFE to $9 \mathrm{~g} \mathrm{~kg}^{-1}$, most of these values decreased significantly. In this study no significant changes were observed in Aspartate Amino Transferase (AST), Alanine Amino Transferase (ALT) and Alkaline Phosphatase (ALP) among dietary treatments at $7 \mathrm{~g} \mathrm{~kg}^{-1}$ of MFE.

The findings are in agreement with the results of Abdulla et al. (2009) who reported Morus alba leaf extract as a non-toxic natural therapeutic agent in rats. However, by increasing the level of MFE to $9 \mathrm{~g} \mathrm{~kg}^{-1}$, the values of ALT, AST and ALP increased. Increased activity of AST, ALT and ALP could be due to damage of liver, kidney, muscle and other tissues (Viveros et al., 2002; Abdel-Tawwab et al., 2007).

Histological study showed that incorporating of MFE at $7 \mathrm{~g} \mathrm{~kg}^{-1}$ diet did not show any negative impact in the liver's tissues however, by increasing the level of MFE to $9 \mathrm{~g} \mathrm{~kg}^{-1}$ diet some abnormalities in the liver appeared. The fish fed with MFE-9 diet did not show uniform hepatocytes and revealed presence of numerous inflammatory cells in inter cellular spaces and in hepatic blood vessels. In contrast, Fiuza et al. (2009) indicated that there were noticeable changes in the hepatopancreas of Nile tilapia induced by incorporation of crude ethanol extract and fractions of Eugenia uniflora (Myrtaceae) in the diet. 


\section{CONCLUSION}

According to the results obtained from the present study, methanol extract of Morus alba at $7 \mathrm{~g} \mathrm{~kg}^{-1}$ of diet had no adverse effect on hematology and liver's histology in African catfish (Clarias gariepinus). Consequently, the extract of Morus alba $\left(7 \mathrm{~g} \mathrm{~kg}^{-1}\right)$ might be a safe dietary supplement to use in the fish production industry.

\section{REFERENCES}

Abdel-Tawwab, M., M.A.A. Mousa, M.H. Ahmad and S.F. Sakr, 2007. The use of calcium pre-exposure as a protective agent against environmental copper toxicity for juvenile Nile tilapia, Oreochromis niloticus (L.). Aquaculture, 264: 236-246.

Abdulla, M.A., M.H. Ali, K.A.A. Ahmed, S.M. Noor and S. Ismail, 2009. Evaluation of the anti-ulcer activities of Morus alba extracts in experimentally-induced gastric ulcer in rats. Biomed. Res., 20: 35-39.

Ahmad, I. and A.Z. Beg, 2001. Antimicrobial and phytochemical studies on 45 Indian medicinal plants against multi-drug resistant human pathogens. J. Ethnopharmacol., 74: 113-123.

Congleton, J.L. and T. Wagner, 2006. Blood-chemistry indicators of nutritional status and food intake in juvenile salmonids. J. Fish Biol., 69: 473-490.

Du, J., Z.D. He, R.W. Jiang, W.C. Ye, H.X. Xu and P.P.H. But, 2003. Antiviral flavonoids from the root bark of Morus alba L. Phytochemistry, 62: 1235-1238.

Enkhmaa, B., K. Shiwaku, T. Katsube, K. Kitajima, E. Anuurad and M. Yamasaki, 2005. Mulberry (M. alba L.) leaves and their major flavonol quercetin 3-(6-malonylglucoside) attenuate atherosclerotic lesion development in LDL receptor-deficient mice. J. Nutri., 135: 729-734.

Fiuza, T.S., C.P. Silva, J.R. de Paula, L.M. Tresvenzol and S.M. Saboia-Morais, 2009. Bioactivity of crude ethanol extract and fractions of Eugenia uniflora (Myrtaceae) in the hepatopancreas of Oreochromis niloticus L. Biol. Res., 42: 401-414.

Harikrishnan, R., C. Balasundaram, M.C. Kim, J.S. Kim, Y.J. Han and M.S. Heo, 2009. Innate immune response and disease resistance in Carassius auratus by triherbal solvent extracts. Fish Shellfish Immunol., 27: 508-515.

Hesser, E.F., 1960. Methods for routine on fish hematology. Prog. Fish Culturist, 22: 164-171.

Houston, A.H., 1990. Blood and Circulation. In: Methods for Fish Biology, Schreck. C.B and P.B. Moyle (Eds.). American Fisheries Society, USA., ISBN: 0-913235-58-X pp: 273-334.
Kang, T.H., J.Y. Hur, H.B. Kim, J.H. Ryu and S.Y. Kim, 2006. Neuroprotective effects of the cyanidin 3-Obeta-d-glucopyranoside isolated from mulberry fruit against cerebral ischemia. Neurosci. Lett., 391: 122-126.

Kim, J.W., S.U. Kim, H.S. Lee, I. Kim, M.Y. Ahn and K.S. Ryu, 2003. Determination of 1-deoxynojirimycin in Morus alba L. leaves by derivatization with 9fluorenylmethyl chloroformate followed by reversedphase high-performance liquid chromatography. J. Chromatog. A, 1002: 93-99.

Kusano, G., S. Orihara, D. Tsukamato, M. Shibano, M. Coskun, A. Guvenc and C.S. Erdurak, 2002. Five new nortropane alkaloids and six new amino acids from the fruit of Morus alba L. growing in Turkey. Chem. Pharm. Bull., 50: 185-192.

Larsen, H.N. and S.F. Snieszko, 1961. Comparison of various methods of determination of haemoglobin in trout blood. Prog. Fish Cult., 23: 8-17.

Larsen, H.N., 1964. Comparison of various methods of hemoglobin detection of channel catfish blood. Prog. Fish-Cult., 26: 11-15.

Miyahara, C., M. Miyazawa, S. Satoh, A. Sakai and S. Mizusaki, 2004. Inhibitory effects of mulberry leaf extract on postprandial hyperglycemia in normal rats. J. Nutr. Sci. Vitaminol., 50: 161-164.

Mohammed, A.K. and A.B. Sambo, 2008. Haematological assessment of the nile Tilapia Oreochromis niloticus exposed to sublethal concentrations of portland cement powder in solution. Int. J. Zool. Res., 4: 48-52.

NRC, 1993. Nutrient Requirements of Fish. 9th Edn., National Academy Press, Washington, DC., USA.

Oku, T., F. Konoshi and N. Hosoya, 1982. Mechanism of inhibitory effect of unavailable carbohydrate on intestinal calcium absorption. J. Nutr., 112: 410-415.

Orwa, C., A. Mutua, R. Kindt, R. Jamnadass and A. Simons, 2009. Agroforestree database: A tree reference and selection guide version 4.0. Nairobi, Kenya. http://eolspecies. lifedesks.org/node/3416.

SAS Institute, 1990. SAS Stat User's Guide. Release 6.08, SAS Institute Inc., Cary, NC., USA.

Van Kampen, E.J. and N.C. Zijlstra, 1961. Determination of haemoglobin. Clin. Chem. Acta, 5: 719-720.

Viveros, A., A. Brenes, I. Arija and C. Centeno, 2002. Effects of microbial phytase supplementation on mineral utilization and serum enzyme activities in broiler chicks fed different levels of phosphorus. Poult. Sci., 81: 1172-1183. 